\title{
Monitoring glacier variations on Geladandong mountain, central Tibetan Plateau, from 1969 to 2002 using remote-sensing and GIS technologies
}

\author{
Qinghua $Y E,{ }^{1,2}$ Shichang KANG, ${ }^{1,3}$ Feng $\mathrm{CHEN}^{1}{ }^{1}$ Jinghua WANG ${ }^{4}$ \\ ${ }^{1}$ Institute of Tibetan Plateau Research, Chinese Academy of Sciences, Beijing 100085, China \\ E-mail: shichang.kang@itpcas.ac.cn \\ ${ }^{2}$ State Key Laboratory of Remote Sensing Science, Institute of Remote Sensing Applications, Chinese Academy of Sciences, \\ Beijing 100101, China \\ ${ }^{3}$ Key Laboratory of Cryosphere and Environment, Cold and Arid Regions Environmental and Engineering Research Institute, \\ Chinese Academy of Sciences, Lanzhou 730000, China \\ ${ }^{4}$ Shandong Normal University, Jinan 250014, China
}

\begin{abstract}
Using Geographical Information System (GIS) and remote-sensing technologies, we describe quantitative measurements of glacier variations in the Geladandong mountain region of central Tibet. Data from Landsat images at three different times, 1973-76, 1992 and 2002, are compared with glacier areas digitized from a topographic map based on aerial photographs taken in 1969. We find that while some glaciers have advanced during the past 30 years, others have retreated. The area of retreat is much larger than that of advance. The total glacier area has decreased from $889 \mathrm{~km}^{2}$ in 1969 to $847 \mathrm{~km}^{2}$ in 2002 , a reduction of almost $43 \mathrm{~km}^{2}$ (i.e. $4.8 \%$ decrease, or an average of $1.29 \mathrm{~km}^{2} \mathrm{a}^{-1}$ ). The variation of glacier area in the Geladandong mountain region is not as large as in other regions within the Tibetan Plateau. Glacier areas decreased $4.7 \mathrm{~km}^{2}$ (i.e. an average of $0.68 \mathrm{~km}^{2} \mathrm{a}^{-1}$ ) during $1969-76,15.4 \mathrm{~km}^{2}$ $\left(0.96 \mathrm{~km}^{2} \mathrm{a}^{-1}\right)$ during $1976-92$, and $22.4 \mathrm{~km}^{2}\left(2.24 \mathrm{~km}^{2} \mathrm{a}^{-1}\right)$ during 1992-2002, suggesting accelerated glacier retreat in recent years. The recession rates of glacier termini also increased. It is likely that the increase in summer air temperature is the major reason for glacier shrinkage in the Geladandong mountain region.
\end{abstract}

\section{INTRODUCTION}

Most of the non-ice-sheet-type glaciers on Earth have receded during the 20th century (Shi and Cheng, 1991; Dyurgerov and Meier, 2000). Alpine glaciers, especially those in temperate zones, are regarded as one of the best natural indicators of climate change (Houghton and others, 2001), including their contribution to eustatic sea-level rise (Meier, 1984). Hence the need for detailed global monitoring of glaciers (Oerlemans, 1994; Haeberli and others, 1999).

Many researchers have focused on alpine glacier variations in the southern Tibetan Plateau/western Himalaya during the last few decades (e.g. Mayewski and Jeschke, 1979; Miller, 1984; Bishop and others, 2004), yet little is known about glacier variations in the central Tibetan Plateau. Results have been published from only a few locations (Liu and others, 2002; Lu and others, 2002). The headwaters of many great rivers, including the Yangtze and Yellow Rivers, are located in the Tibetan Plateau and are economically important downstream. It is essential and urgent for us to monitor glacier variations within the entire Tibetan Plateau.

Geladandong mountain, the highest peak in the Tanggula Mountains, with an elevation of $6621 \mathrm{~m}$ a.s.l., is located in the central Tibetan Plateau (Fig. 1). The Tanggula Mountains serve as a geographical boundary between the continental climate and the summer Indian monsoon over the Tibetan Plateau (Zheng and Zhu, 2003). The north is subject to continental air masses, whereas the south is influenced by air masses from the summer monsoon. The two air masses meet between $32^{\circ}$ and $34^{\circ} \mathrm{N}$. The headwaters of the Yangtze
River are located in the Geladandong mountain region $\left(33^{\circ} 02^{\prime}-33^{\circ} 41^{\prime} \mathrm{N}, 90^{\circ} 42^{\prime}-91^{\circ} 41^{\prime} \mathrm{E}\right)$. In this paper, we use three series of Landsat images from various periods to study glacier variations in the Geladandong mountain region.

Because of the large number and remoteness of most alpine glaciers, satellite-based remote-sensing techniques, including microwave data and optical imagery, have commonly been used in global-scale surveys. Landsat imagery, including the Landsat Multispectral Scanner (MSS; images of four spectral bands in the visible/near-infrared (VNIR) parts, with a pixel resolution of $79 \mathrm{~m}$ ), the Landsat Thematic Mapper (TM; images of seven spectral bands from the visible to the thermal-infrared parts with $28.5 \mathrm{~m}$ pixel resolution in the VNIR) and the Landsat Enhanced Thematic Mapper Plus (ETM+; images of eight discrete spectral bands with a $14.25 \mathrm{~m}$ pixel resolution in the panchromatic band), has been one of the primary data sources for glaciological research (Bindschadler and others, 2001; R.S. Williams, Jr and J.G. Ferrigno, http://pubs.usgs.gov/fs/2005/3056/fs20053056.pdf). Landsat data have provided glacier information in remote areas since the beginning of the series in 1972 (Meier, 1973). In this work, glacier variations have been measured using a series of digital images since 1973, including Landsat MSS in 1973 and 1976 (1973-76, i.e. mosaic image from 1973 and 1976 to cover the entire Geladandong mountain region), TM in 1992 and ETM+ in 2002 (Table 1). The 2002 ETM+ is a scene with a slight snow cover that could be distinguished easily from the glaciers in the false-color image (RGB: 432). The 1992 and 1973-76 images are free of snow cover. The geometric resolution of optical bands of Landsat imagery in 2002 was improved by 


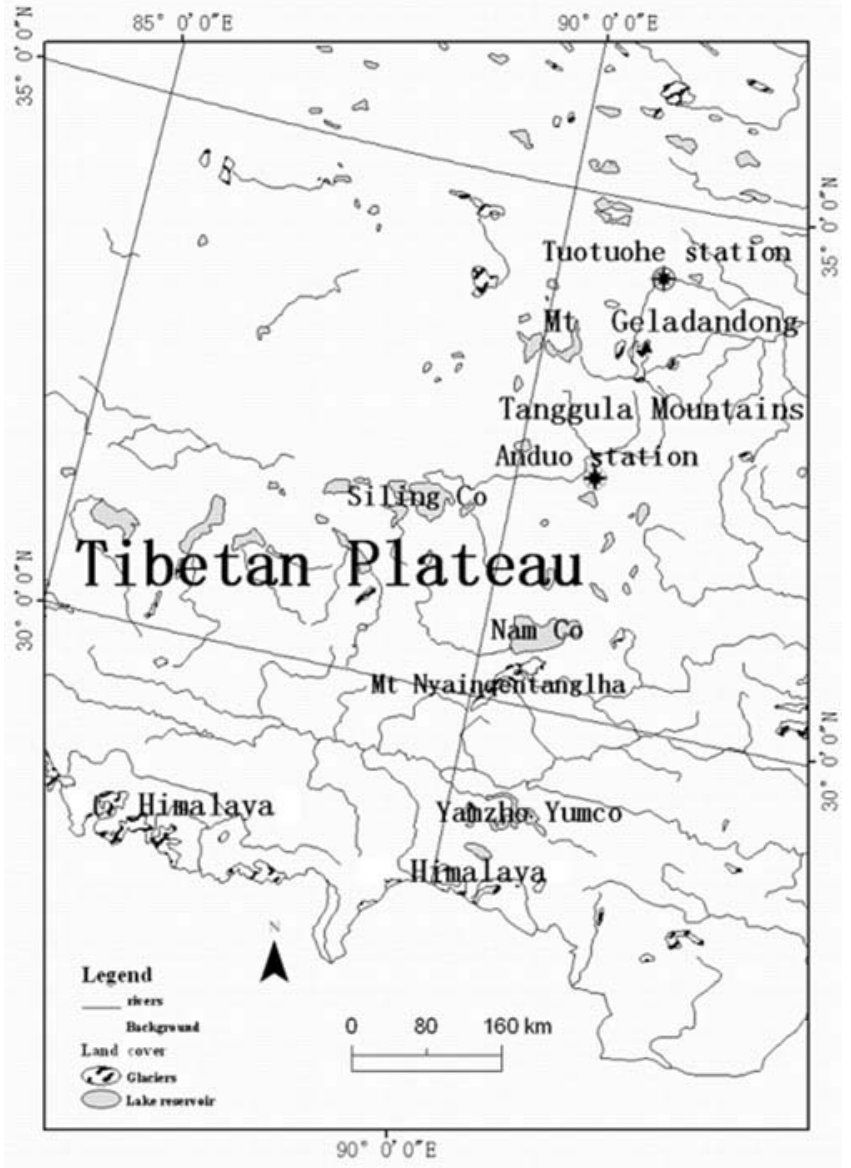

Fig. 1. Location map around Geladandong mountain in the central Tibetan Plateau.

data fusion, using the $14.25 \mathrm{~m}$ panchromatic band of ETM+, so that glacier interpretation could be improved.

We also use topographic maps at 1:100000 (with about $\pm 100 \mathrm{~m}$ accuracy), which were compiled from snow-free aerial photographs taken in November 1969. The map area was surveyed and mapped by the State Bureau of Surveying and Mapping in China in June 1974.

The multispectral classification methods for glacier delineation with Landsat TM data include manual digitization, normalized difference snow index (Silverio and Jaquet, 2005), spectral-band ratio, and unsupervised and supervised classification techniques (Hall and Martinec, 1985; Paul and others, 2002; GLIMS Algorithm Working Group, www.geo.unizh.ch/ kaeaeb/glims/algor.html\#Anchor23240). Although on-screen digitizing by manual delineation of glacier ice is very time-consuming and laborintensive, it is still widely used (Williams and others, 1997; Raup and others, 2000; Khalsa and others, 2004; Khromova

Table 1. Landsat (MSS, TM and ETM+) data used in this work

\begin{tabular}{lll}
\hline Sensor & Date & Path/row \\
\hline MSS & & \\
MSS & 10 June 1973 & $149 / 37$ \\
TM & 17 December 1976 & $148 / 37$ \\
ETM+ & 31 August 1992 & $138 / 37$ \\
& 15 May 2002 & $138 / 37$ \\
\hline
\end{tabular}

and others, 2006), especially when the analyst knows the area well and is knowledgeable about its glaciers. Aizen and others (2006), for example, studied glacier changes in the central and northern Tien Shan and achieved maximum accuracy for the glacier boundaries by manually digitizing false-color composites of VNIR bands. For debris-covered glaciers, many semi-automatic methods have been utilized in recent years (for example Paul and others, 2004; Silverio and Jaquet, 2005).

The very low reflectance of ice and snow in the middle infrared has been widely used for glacier classification, for example with threshold ratio images from raw data of digital number of TM bands 4 and 5 (Bayr and others, 1994; Jacobs and others, 1997; Paul, 2001). This technique has proved to be simple, robust and accurate (Paul and others, 2002). It has also been proposed as a method for reducing multiple effects (e.g. the topographic effect of direct light) within multispectral data (Kriegler and others, 1969; Crane, 1971; Vincent, 1973; Holben, 1981). However, data adjustments (e.g. compensation for data offsets prior to ratio) should be considered an essential part of the band-ratioing process, especially for scenes containing deep shadow (Crippen, 1988). The data offsets inherent in the band data can affect results of the ratio image. As we do not know the suitable offsets for the adjustment, we use images that result from subtracting band 5 from band 4 (TM4 - TM5) to discern the glacierized areas, including termini of individual glaciers, in the Geladandong mountain region after orthorectification and co-registration of all image scenes acquired on different dates. Orthorectification by digital elevation model (DEM) applications is employed to eliminate the effects of perspective distortion and to reduce the topographic effect on remotely sensed data (Justice and others, 1981; Kääb, 2002, 2005).

\section{METHODOLOGY}

\section{DEM data}

The multitemporal and multi-source datasets must be accurately co-registered and orthorectified, using a DEM, before calculating glacier area changes based on pixels. Thus, DEM evaluation has to be carried out first. For the study site, we have DEM data at the 1:250000 scale (DEM25), which were created by contour digitization and interpolation from the 1:250000 topographic map compiled by the State Bureau of Surveying and Mapping in China. The DEM cell size is $100 \mathrm{~m}$, and its co-registered error to the topographic map of 1969 is within $100 \mathrm{~m}$.

The height accuracy of the basic DEM data was evaluated by calibrating 160 elevation check points on the $1: 100000$

Table 2. Errors in co-registration of satellite images to the $1: 100000$ topographic map of the Geladandong mountain region

\begin{tabular}{lll}
\hline Imagery & $\begin{array}{c}\text { Pixel resolution } \\
\text { m }\end{array}$ & rmse \\
& & pixel \\
\hline 10 June 1973 (149/37) & 79 & 0.20 \\
17 December 1976 (148/37) & 79 & 0.20 \\
31 August 1992 (138/37) & 28.5 & 0.11 \\
15 May 2002 (138/37) & 14.25 & 0.10 \\
\hline
\end{tabular}




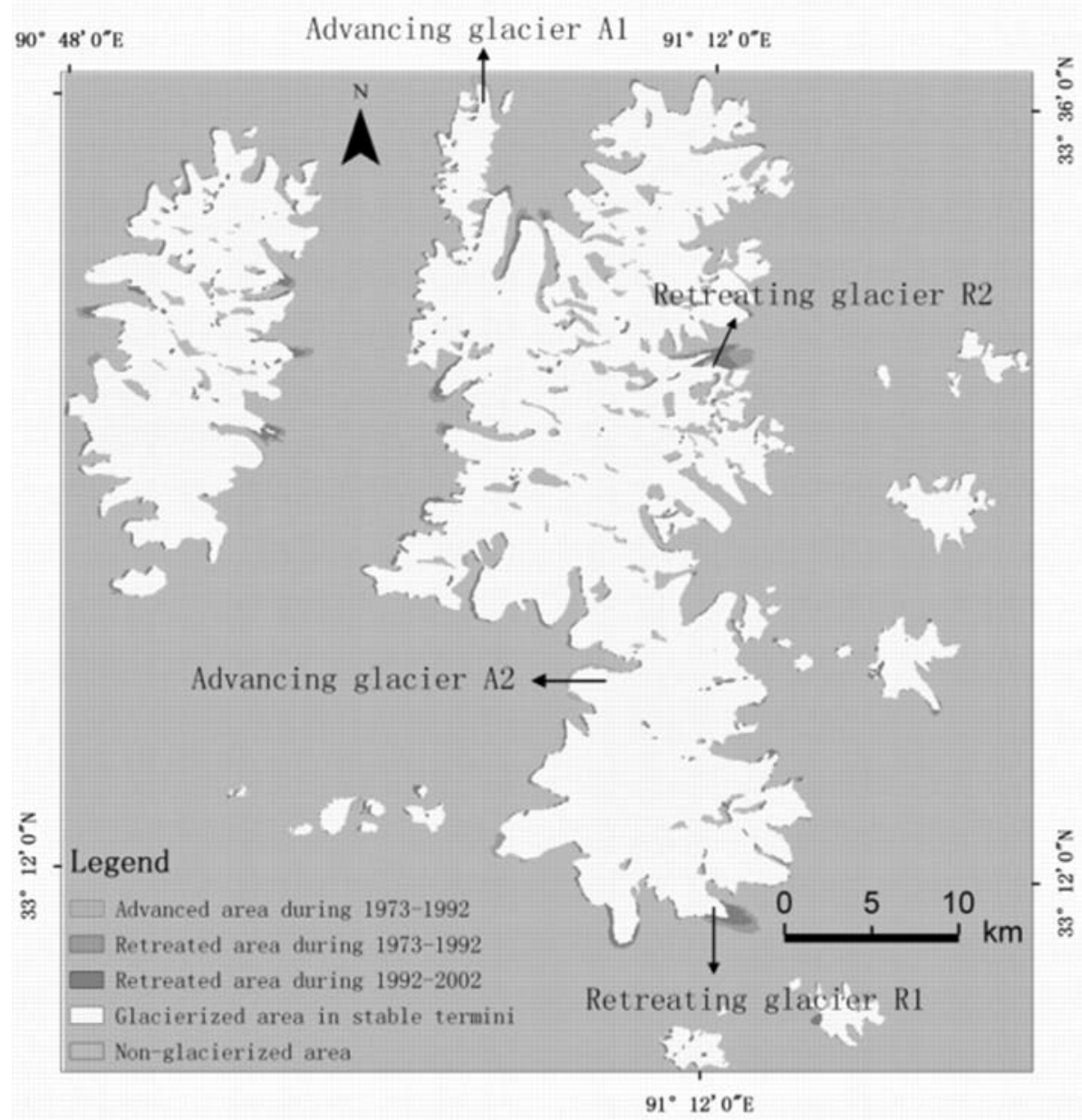

Fig. 2. Glacier variations in the Geladandong mountain region during 1973-2002.

1969 topographic maps, with the corresponding elevation values for the same locations from the terrain data before orthorectification of the sequential satellite imagery. We obtained an average deviation of the elevations of $32.85 \mathrm{~m}$, and a standard deviation of the elevation differences of $45.22 \mathrm{~m}$, with reference to the $1: 100000$ topographic map. The root-mean-square error (rmse) of vertical deviations for DEM25 (Stevens and others, 2004) is $\pm 54.42 \mathrm{~m}$, with maximum vertical deviations of -167 and $+72 \mathrm{~m}$. We used the DEM25 for orthorectification of the three sets of Landsat images. The digital images we used were converted from disparate sources to a common format defined in Arc/Info Grid with transverse Mercator projection and Krasovsky 1940 spheroid. Co-registration for all orthoimages is based on the $1: 100000$ topographic map (which is used as the common 'base'), and the co-registered errors are within 0.5 pixel (Table 2 ).

\section{Delineation of glaciers and detection of variation}

The study of glacier variations depends mainly on the delineation of the glaciers from sequential, co-registered orthorectified images. We know, both from field surveys in October 2005 and from the series of Landsat images, that there are no debris-covered glaciers in this region. A classification scheme was used in which non-glacierized areas were assigned a single-digit value of 5, and glacier areas were assigned a single-digit value of 7 . Glaciers are mapped from Landsat TM and ETM+ images of 1992 and
2002, by unsupervised classification of imagery from band arithmetic (TM4 - TM5). Glaciers from Landsat MSS images of 1973-76 are mapped by unsupervised classification from false-color composite images which were constructed using MSS bands 4, 2 and 1 (i.e. RGB: 421). All results were resampled to the same $28.5 \mathrm{~m}$ gridcell resolution, and some snow-covered, non-glacierized areas were eliminated by filter methods and manual editing. Classification accuracy for glacier delineations depends not only on the pixel resolution but also on the season when the imagery is taken. Although the image derived from spectral-band-algebraic operation (TM4 - TM5) works well for snow and ice, manual corrections are also required. The classification results of each individual image are more accurate if glaciological and field survey knowledge is applied to the glacier interpretation, as was done by Williams and others (1997) on Vatnajökull, Iceland.

The classification scheme facilitated the algebraic operations in the Arc/Info Grid module. The one-digit value (i.e. 5 or 7) from each gridcell was integrated over the three images (1973-76, 1992 and 2002) by map algebra to generate a spatial-temporal integrated dataset with a three-digit value in each gridcell that simulated glacier change during the period 1973-2002 (Fig. 2). This hybrid-grid method enables us to track glacier variations during the corresponding period both on maps and in tables (Ye and others, 2006). Instances in which gridcells indicated changes that occurred more rapidly than was considered feasible $(575,757$, etc.) 


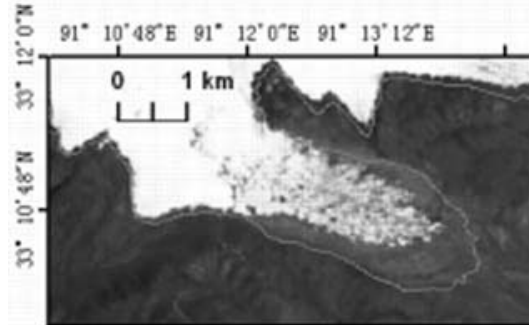

$A(a)$ Glacier $R 1$ in 1998

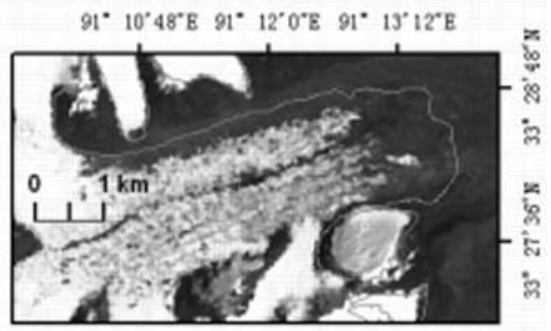

A(b) Glacier $\mathrm{R} 2$ in 1992

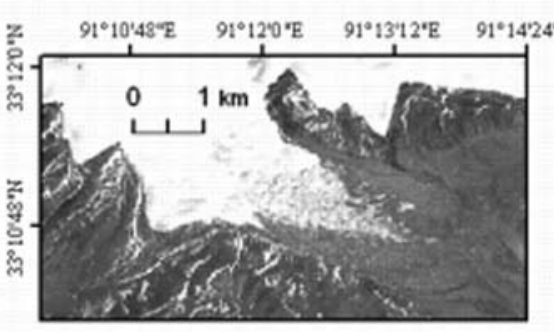

$\mathrm{B}(\mathrm{a})$ Glacier $\mathrm{R} 1$ in 2002

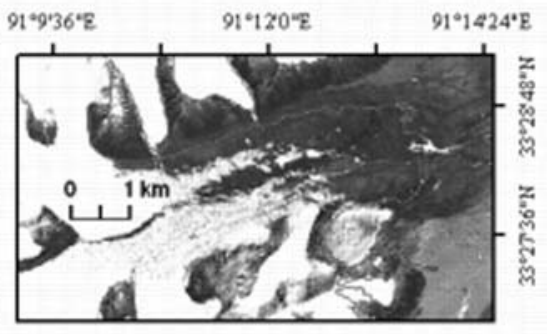

$B(b)$ Glacier $\mathrm{R} 2$ in 2002

Fig. 3. Areas of retreating glaciers compared to the glacier extents on the 1969 topographic map. (a) Glacier R1 in 1992 Landsat TM image (bands 4, 3 and 2). (b) Glacier R2 in 1992 Landsat TM image (bands 4, 3 and 2). (c) Glacier R1 in 2002 Landsat ETM+ image (pansharpened with band 8). (d) Glacier R2 in 2002 Landsat ETM+ image (pansharpened with band 8).

were rejected as 'noise'. These may be caused by false information or changes outside the expected range, such as different data sources or seasonal differences in snow cover in non-glacierized areas. The three-digit value from each gridcell was used to identify areas of glacier advance where non-glacierized areas became glacier areas, and areas of glacier retreat where glacier areas became non-glacierized during different periods (Ye and others, 2006). These regions could be identified from the map (Fig. 2).

Glacier retreat is evident at the glacier terminus or from changes in glacier geometry (nunataks) which result in separate flowlines (Paul and others, 2004). Length changes were derived from the average, over three measurements, of the difference in glacier tongue positions between the glacier outline in the 1969 topographic map and individual images along the central flowline. The Earth Resource Data Analysis System (ERDAS) measurement software tool was used.

\section{Accuracy of measurements}

The measurement accuracy of the position of the glacier front is limited by the sensor resolution (Williams and others,

Table 3. Glacier variation during 1973-2002 in the Geladandong mountain region

\begin{tabular}{lrl}
\hline Grid value & \multicolumn{1}{c}{$\begin{array}{c}\text { Area } \\
\mathrm{km}^{2}\end{array}$} & \\
& & \\
& & \\
& & \\
577 & $1.68 \pm 0.028$ & Advanced area, 1973-92 \\
557 & $16.32 \pm 0.028$ & Advanced area, 1992-2002 \\
755 & $30.83 \pm 0.028$ & Retreated area, 1973-92 \\
775 & $815.03 \pm 0.028$ & Clacierized area in stable termini \\
777,757 & $2322.19 \pm 0.028$ & Non-glacierized area \\
555,575 & & \\
\hline
\end{tabular}

1997) and co-registration error (Hall and others, 2003; Silverio and Jaquet, 2005). Since glacier variations are determined by values of the integrated grids (Fig. 2; Table 3) from the three digital images (from 1973-76, 1992 and 2002) together, the errors of co-registration to the 1969 topographic base map (with pixel resolution $100 \mathrm{~m}$ ) play a very important role (equal to that of the sensor resolution) in the measurement. According to Williams and others (1997), Hall and others (2003) and Silverio and Jaquet (2005), for multitemporal measures of glacier-front position using satellite images, each position has an uncertainty that can be calculated by

$$
U_{\mathrm{T}}=\sqrt{\sum \lambda^{2}}+\sqrt{\sum \varepsilon^{2}},
$$

where $U_{\mathrm{T}}$ is the measurement uncertainty of the glacier terminus, $\lambda$ is the original pixel resolution of each individual image and $\varepsilon$ is the registration error of each individual image to the 1969 topographic map.

In our case, according to the above equation, glacier terminus measurement uncertainty is $148,115,111,99$ and $46 \mathrm{~m}$ between each pair of datasets (i.e. 1969-73, 1969-92, 1969-2002, 1973-92, 1992-2002), respectively. The total

Table 4. Glacier area in different periods in the Geladandong mountain region

\begin{tabular}{lcccc}
\hline Year & Glacierized area & Variation in area & $\begin{array}{c}\text { Variation } \\
\text { rate }\end{array}$ & Speed \\
& $\mathrm{km}^{2}$ & $\mathrm{~km}^{2}$ & $\%$ & $\mathrm{~km}^{2} \mathrm{a}^{-1}$ \\
& & & & \\
\hline 1969 & $889.31 \pm 0.02$ & & & \\
$1973-76$ & $884.57 \pm 0.017$ & $-4.74 \pm 0.039$ & 0.53 & -0.68 \\
1992 & $869.17 \pm 0.002$ & $-15.4 \pm 0.018$ & 1.74 & -0.96 \\
2002 & $846.81 \pm 0.0007$ & $-22.36 \pm 0.003$ & 2.57 & -2.24 \\
Total & & $-42.5 \pm 0.042$ & 4.78 & -1.29 \\
\hline
\end{tabular}



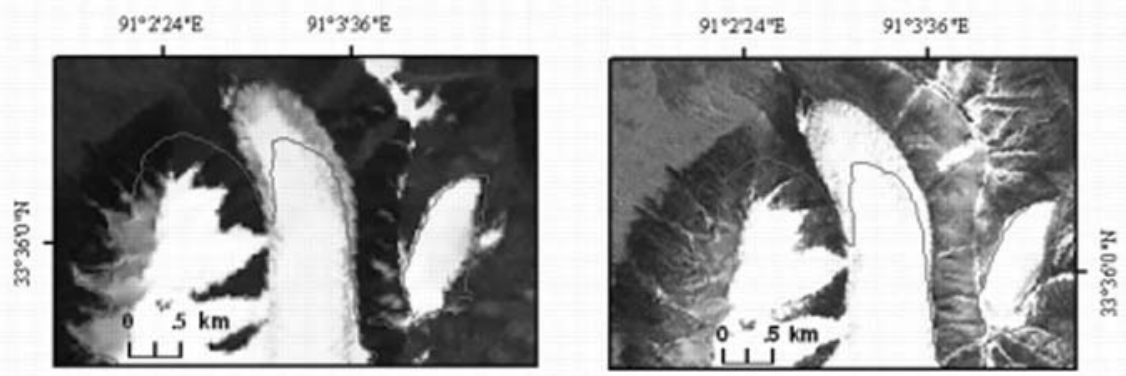

Fig. 4. Areas of advancing glacier A1 compared to its extent on the 1969 topographic map. (a) 1992 Landsat TM image (bands 4, 3 and 2). (b) 2002 Landsat ETM+ image (pansharpened with band 8).

$U_{\text {T }}$ among three images was $90 \mathrm{~m}$ during 1973-2002, and among four images was $156 \mathrm{~m}$ during 1969-2002.

Measurement accuracy of the glacier area from individual spatial data is also limited by the sensor resolution. According to Hall and others (2003), the measurement uncertainty in glacier area $\left(U_{\mathrm{A}}\right)$ from images can be obtained using

$$
U_{\mathrm{A}}=\frac{2 U_{\mathrm{T}}}{\sqrt{\sum \lambda^{2}}} \sum \lambda^{2}=2 U_{\mathrm{T}} \sqrt{\sum \lambda^{2}} .
$$

The area accuracy in any one individual digital image can be expressed as

$$
U_{M}=2 U_{T} \lambda,
$$

where $U_{M}$ is the area uncertainty of the spatial data (digital image, topographic map, etc.). Uncertainties in the glacierized area in our case are shown in Table 4.

As the co-registration error also plays an important role in variation measurement between datasets, we included the registration error in the area accuracy calculation. Thus, changes in the area extent of a glacier during 1969-2002 with four spatial datasets were measured with an accuracy of $\pm 0.042 \mathrm{~km}^{2}$ using

$$
U_{\mathrm{A}}=2 U_{\mathrm{T}} \sqrt{\sum \lambda^{2}}+\sum \varepsilon^{2} .
$$

In our case:

$$
\begin{aligned}
U_{\mathrm{A}}= & 2 \times 156 \times \sqrt{100^{2}+79^{2}+28.5^{2}+14.25^{2}} \\
& +\left[(0.20 \times 100)^{2}+(0.20 \times 100)^{2}+(0.11 \times 100)^{2}\right. \\
& \left.+(0.10 \times 100)^{2}\right] \\
\leq & 40985+1021 \\
\approx & 42006 \mathrm{~m}^{2} .
\end{aligned}
$$

In the same way, the total measurement uncertainty in glacier area during 1973-2002 among the three digital images was $\pm 0.028 \mathrm{~km}^{2}$. All area variation uncertainties are shown in Tables 3 and 4.

\section{RESULTS}

Values of the integrated grid from the three digital images (Fig. 2; Table 3) show that, while some glaciers in the Geladandong mountain region advanced during 19732002, others retreated. The area of glacier recession was much larger than that of glacier advance (Table 3). We also see that the areas of glacier advance decrease while the areas of glacier retreat increase through the time period.
From calculation of glacier area derived from classification of digital images, and from the 1969 topographic map, we determine that total glacier recession from 1969 to 2002 was $\sim 43 \mathrm{~km}^{2}$. The glacierized area in the Geladandong mountain region, from the 1969 map, was $889 \mathrm{~km}^{2}$; the image mosaic of 1973 and 1976 indicated it decreased to $885 \mathrm{~km}^{2}$ (Table 4). Glacier area decreased by $22 \mathrm{~km}^{2}$ (i.e. $2.2 \mathrm{~km}^{2} \mathrm{a}^{-1}$ ) during 1992-2002, compared to $15.4 \mathrm{~km}^{2}$ $\left(1.0 \mathrm{~km}^{2} \mathrm{a}^{-1}\right)$ during 1973-92, and $4.7 \mathrm{~km}^{2} \quad\left(0.7 \mathrm{~km}^{2} \mathrm{a}^{-1}\right)$ during 1969-73 (Table 4; Fig. 2). The area recession rate in Table 4 indicates that glacier retreat has accelerated in recent years.

The recession rates of some glacier termini in the Geladandong mountain region have also increased. For example, the terminus retreat of glacier R1, located in the south of the region (Fig. 2), was $983 \pm 115 \mathrm{~m}$ from 1969 to 1992, an average retreat rate of $43 \mathrm{~m} \mathrm{a}^{-1}$, while it was $2018 \pm 111 \mathrm{~m}$ from 1969 to 2002 a retreat rate of $61 \mathrm{~m} \mathrm{a}^{-1}$ (Fig. 3a and c). This indicates that the glacier tongue retreated $1035 \pm 46 \mathrm{~m}$ during $1992-2002\left(104 \mathrm{~m} \mathrm{a}^{-1}\right)$. Similarly, the tongue of glacier R2, located in the northeast of the region (Fig. 2), retreated $1740 \pm 115 \mathrm{~m}\left(76 \mathrm{~m} \mathrm{a}^{-1}\right)$ during

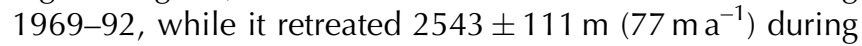
1969-2002 (Fig. 3b and d). This suggests the tongue retreated

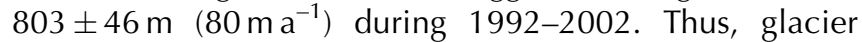
recession has accelerated in recent years. This is the major characteristic of glaciers in the study area during 1969-2002.

Meanwhile, other glaciers in the Geladandong mountain region advanced $4.1 \pm 0.028 \mathrm{~km}^{2}$ in total during 1973-92 and $1.68 \pm 0.028 \mathrm{~km}^{2}$ during 1992-2002 (Table 3). Glacier A1, which is located in the northern part of the region (Fig. 2), advanced $535 \pm 115 \mathrm{~m}\left(23 \mathrm{~m} \mathrm{a}^{-1}\right)$ during 1969-92, and $607 \pm 111 \mathrm{~m}\left(18 \mathrm{~km}^{2} \mathrm{a}^{-1}\right)$ during 1969-2002 (Fig. 4). Thus, the terminus advanced $72 \pm 46 \mathrm{~m}\left(6 \mathrm{ma}^{-1}\right)$ during 1992-2002, much slower than in the previous period. The tongue of glacier A2, which is located in the southwestern part of the area (Fig. 2), advanced $311 \pm 115 \mathrm{~m}$ (14 $\mathrm{m} \mathrm{a}^{-1}$ ) during 1969-92; its advance could not be detected using Landsat TM/ETM+ imagery during 1992-2002 (Fig. 2). Advancing glaciers are generally located in the northern and western parts of the region, while glacier retreat dominates in the southern and eastern parts (Fig. 2).

\section{DISCUSSION}

\section{Misclassifications from individual images}

Availability of cloud-free, end-of-ablation-period satellite scenes with appropriate glacier mapping conditions (cloudand snow-free) is limited. Glacier monitoring by means of 
optical sensors is hampered by frequent cloud cover or perennial snowfields that are attached to some glaciers (Williams and others, 1997). Because glacier and snow cover vary during different seasons, it is difficult to delineate glaciers from surrounding snowpack (the snow-covered, non-glacierized area) with only spectral characteristics of individual satellite images. Local knowledge gained from experience in the field (e.g. Williams and others, 1997) is very advantageous. In addition, some misclassifications can exist among sequential images due to different observation times, pixel resolutions and data sources.

The misclassification of non-glacierized areas as glacier areas in the earlier maps/images resulted in an overestimate of glacier retreat during the corresponding period. For example, the smaller remaining 'noise' (small red areas in Fig. 2) comes from some non-glacierized areas surrounded by glacier areas (e.g. high mountain rock ridges, steep mountain peaks) which are misidentified as glacierized areas on earlier images (e.g. the 1992 image). They are however, correctly identified as non-glacierized areas on the 2002 image. Similarly, the misclassification of non-glacierized areas as glacier areas in the later images resulted in an overestimate of glacier advance during the corresponding period. The blue area in Figure 2, for example, is marked as 'advancing' during 1973-92. Some of the blue, however, does not occur at glacier termini, and cannot be regarded as advancing.

The hybrid-grid method enables the 'noise' to be identified both in spatial characteristics (Fig. 2) and in value (Table 3), which effectively improves the accuracy in detecting areas of glacier retreat and advance. We can reclassify the misclassified gridcells (Table 3 ), if there is an agreement with at least two other images (757, 575, etc.). The rules for reclassification are very important for detection and elimination of discrepancies in the hybrid grid. We will discuss the 'noise' between various data sources elsewhere. Meanwhile, we can further improve the accuracy of our results by utilizing the knowledge of glaciologists to correctly identify certain areas as glacierized or nonglacierized in the hybrid grid and work to verify the problematic areas with future field surveys.

\section{Uncertainties of measurement}

The uncertainties in area and length measurements can be considerable when comparing satellite data with topographic maps. Uncertainties have reduced with time, however, as pixel resolution of satellite images has improved, as shown by Hall and others (2003) who considered the errors inherent in mapping historical glacier positions in Austria from the ground and space. The equations that we use to calculate uncertainties need to be improved. First, the error in registration to the topographic base map is limited, to some extent, by the pixel resolution. Thus, the registration error and pixel resolution are not independent of each other, and their relationship in the measurement should be considered when calculating the uncertainties. Second, in the hybridgrid development of each of the three images (1973-76, 1992 and 2002) based on a unified pixel resolution, the errors in co-registering to the 1969 topographic base map are not always enlarged by equal weight. The larger registration error image may play a more important role than the smaller registration error image in the measurement of uncertainties for the hybrid grid. Third, much of the mismatched and misclassified information between individual images can be detected and eliminated in the integrated grid (pixel size is $28.5 \mathrm{~m}$ ). The hybrid and the reclassification of gridcells could reduce the measurement uncertainty to some extent (e.g. 575, 757). Therefore, uncertainties we provide are the maximum values (e.g. $\pm 156 \mathrm{~m}$ for terminus position, and $\pm 0.042 \mathrm{~km}^{2}$ for the area, for 1969-2002). Further work is required for a more elaborate depiction of uncertainties in the analysis of glacier variations by the hybrid-grid method.

\section{Glacier variations over the Tibetan Plateau}

Our results show that the recession of glaciers in the Geladandong mountain region is less than in other regions in China (see also Lu and others, 2002), but the recession has accelerated in recent years. During 1969-2002, glacier area decreased by a total of $43 \mathrm{~km}^{2}$, or $4.8 \%\left(0.15 \% \mathrm{a}^{-1}\right)$ of the total area $\left(889 \mathrm{~km}^{2}\right)$ in 1969 (Table 4). This is much smaller than the average $7 \%$ retreat $\left(0.18 \% \mathrm{a}^{-1}\right)$ for glaciers across China since the 1960s (Yao and others, 2004). Alpine glacier recessions are occurring throughout Asia (e.g. 8.4\% decrease in glacier area during 1976-2003 in the Naimona'nyi region of the western Himalaya (Ye and others, 2006); $13.8 \%$ decrease in the Urumqi river drainage area during 1964-92 (Chen and others, 1996); 17\% decrease in the A'nyêmaqên Shan from the headwaters of the Yellow River during 1966-2000 (Yang and others, 2003); 10.3\% decrease in the western part of the Qilian Shan during 1956-90 (Liu and others, 2002); 9\% decrease in the Pumqu river basin between the 1970s and 2001 (Jin and others, 2005); and 4\% decrease of July 1st glacier from 1985 to 2002 (Sakai and others, 2006)). The accelerated retreat in recent years observed in this study is consistent with the results of Yao and others (2004).

\section{Reasons for glacier variations}

Glacier variations are concurrent with the changes of summertime air temperature during the past 40 years, according to meteorological data from Tuotuohe station (4533 ma.s.l.) and Anduo station (4800 ma.s.l.), which are the closest stations to Geladandong mountain (Fig. 1). Figure 5 shows a time series of summer air temperature (May through September where monthly mean temperature is above $0^{\circ} \mathrm{C}$ ) and annual precipitation, along with linear fits and 5 year fast Fourier transform smoothing. Annual precipitation at Anduo increases (Fig. 5b), while no clear trend is evident at Tuotuohe (Fig. 5d). However, a rise in summer air temperature at both stations is clear, especially since the 1990s (Fig. 5a and c). Rising temperature in the Geladandong mountain region is consistent with a prevailing warming over the Tibetan Plateau during the last few decades (Liu and Chen, 2000). Temperature rise causes stronger summer melting and a corresponding negative mass balance on the glaciers, which leads to a reduction in glacier area and retreat of glacier termini (Yao and others, 2004). Recession of glaciers in the Geladandong mountain region has accelerated during the past decade, also in concert with dramatic warming in the region during the same period. The glacier recession may also be part of a longer-term response (Oerlemans, 2005; Kerr, 2006), perhaps over many hundreds of years. Su and Shi (2002) concluded that since the maximum of the Little Ice Age (17th century) the mean temperature of monsoonal temperate glaciers in China has risen by $0.81{ }^{\circ} \mathrm{C}$ and that glacier area has decreased by $3921.2 \mathrm{~km}^{2}$, an amount equivalent to $30 \%$ of the modern glacier area. 

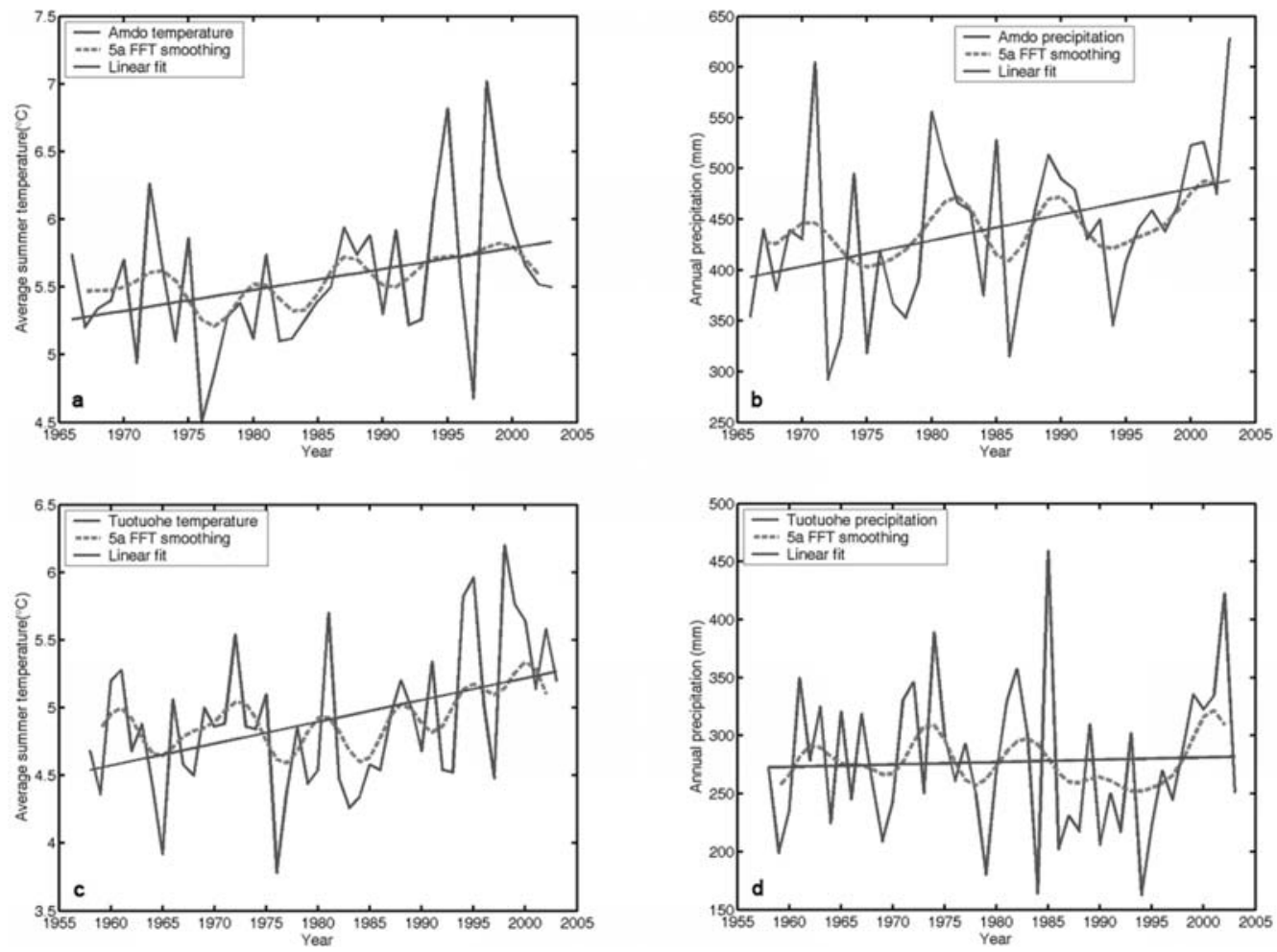

Fig. 5. Comparison between climatic parameters and glacier variations. (a) Average summer (May to September) temperature $\left({ }^{\circ} \mathrm{C}\right.$ ) from Anduo station (1966-2003). (b) Annual precipitation (mm) from Anduo station (1966-2003). (c) Average summer (May to September) temperature $\left({ }^{\circ} \mathrm{C}\right)$ from Tuotuohe station (1958-2003). (d) Annual precipitation (mm) from Tuotuohe station (1958-2003).

Despite the observations above, the reasons for glacier advances in the Geladandong mountain region have not yet been studied. They might be due to glacier surges (Chinn and others, 2005; Larsen and others, 2006), or to locally increased precipitation not detected by the sparse meteorological stations (e.g. Chinn and others (2005) who considered recent glacier advances in Norway and New Zealand, and Hooker and Fitzharris (1999) who examined correlations between climatic parameters and the retreat and advance of Franz Josef Glacier, New Zealand). It is not clear at present whether the glacier advances are caused by the effects of glacier dynamics or local climate.

\section{Future research}

To date, our work has focused only on variations of glacier area. It has not included vertical variation due to downwasting. We continue to investigate methods to calculate vertical variations from two DEMs from different times to study the volume variation of glaciers. This will enable us to generate a more comprehensive view of glacier variations in the Geladandong mountain region. It will also require detailed studies with various data sources and more intensive field surveys.

\section{CONCLUSIONS}

We have presented a method for investigation of glacier variations using GIS and remote-sensing technologies. By developing a hybrid classification of results from time-based digital images on gridcells, most of the glacier variations and misclassifications could be identified both in the synthetic map (Fig. 2) and the tables (Table 3). However, the measurement uncertainty for the hybrid-grid method needs to be studied further due to the dependent relationship between the registration error and the pixel resolution of the original data.

Our results show that while some glaciers in the Geladandong mountain region of the central Tibetan Plateau have advanced over the past three decades, others have retreated. Retreating glaciers prevail. Glacier area has reduced at a rate of $1.29 \mathrm{~km}^{2} \mathrm{a}^{-1}$ during $1969-2002$. In addition, glacier area recession has accelerated in recent years. The speed of glacier termini retreat has also increased. The change in glacier area in the region $(4.8 \%)$ is less than the average rate $(7 \%)$ over the high Asian plateau.

Acceleration of glacier shrinking is consistent with a dramatic increase in summer air temperature during the last decade, suggesting that summer temperature has played an important role in glacier variations in the Geladandong mountain region during 1969-2002. However, the reason for the spatial difference in the glacier variations (especially for the advancing glaciers) cannot be clarified without further detailed studies and in situ field surveys.

\section{ACKNOWLEDGEMENTS}

This research is supported by the National Nature Science Foundation of China (40401054, 40121101), the Chinese Academy of Sciences ('Talent Project', KZCX3-SW-339/ 334), the National Basic Research Program of China (2005CB422004) and the US National Oceanic and Atmospheric Administration (NA04OAR4600179). We thank C. Zhu, P.A. Mayewski, G. Hamilton, S. Kaspari, B. Grigholm, A. Kurbatov, Y. Wang and Y. Zhu for helpful suggestions. We also greatly appreciate helpful comments on the manuscript from R.S. Williams Jr, an anonymous 
referee and F. Paul. Constructive comments and generous efforts to improve this paper from the Scientific Editor, R. Naruse, are acknowledged and deeply appreciated.

\section{REFERENCES}

Aizen, V.B., V.A. Kuzmichenok, A. Surazakov and E. Aizen. 2006. Glacier changes in the central and northern Tien Shan during the last 140 years based on surface and remote-sensing data. Ann. Glaciol., 43, 202-213.

Bayr, K.J., D.K. Hall and W.M. Kovalick. 1994. Observations on glaciers in the eastern Austrian Alps using satellite data. Int. J. Remote Sensing, 15(9), 1733-1752.

Bindschadler, R., J.A. Dowdeswell, D. Hall and J.G. Winther. 2001. Glaciological applications with Landsat-7 imagery: early assessments. Remote Sens. Environ., 78(1-2), 163-179.

Bishop, M.P. and 16 others. 2004. Global land ice measurements from space (GLIMS): remote sensing and GIS investigations of the Earth's cryosphere. Geocart. Int., 19(2), 57-84.

Chen, J., C. Liu and M. Jin. 1996. Application of the repeated aerial photogrammetry to monitoring glacier variation in the drainage area of the Ürümqi River. J. Glaciol. Geocryol., 18(4), 331-336. [In Chinese with English summary.]

Chinn, T., S. Winkler, M.J. Salinger and N. Haakensen. 2005. Recent glacier advances in Norway and New Zealand: a comparison of their glaciological and meteorological causes. Geogr. Ann., 87(1), 141-157.

Crane, R.B. 1971. Preprocessing techniques to reduce atmospheric and sensor variability in multispectral scanner data. In Proceedings of the 7th International Symposium on Remote Sensing of the Environment, vol. II, Ann Arbor, MI, USA, 1345-1355.

Crippen, R.E. 1988. The dangers of underestimating the importance of data adjustments in band ratioing. Int. J. Remote Sensing, 9(4), 767-776.

Dyurgerov, M.B. and M.F. Meier. 2000. Twentieth century climate change: evidence from small glaciers. Proc. Natl. Acad. Sci. USA (PNAS), 97(4), 1406-1411.

Haeberli, W., R. Frauenfelder, M. Hoelzle and M. Maisch. 1999. On rates and acceleration trends of global glacier mass changes. Geogr. Ann., 81A(4), 585-591.

Hall, D.K. and J. Martinec. 1985. Remote sensing of ice and snow. London and New York, Chapman and Hall Ltd.

Hall, D.K., K.J. Bayr, W. Schöner, R.A. Bindschadler and J.Y.L. Chien. 2003. Consideration of the errors inherent in mapping historical glacier positions in Austria from ground and space (1893-2001). Remote Sens. Environ., 86(4), 566-577.

Holben, B.N. 1981. An examination of spectral band ratioing to reduce the topographic effect on remotely sensed data. Int. J. Remote Sensing, 2(2), 115-133.

Hooker, B.L. and B.B. Fitzharris. 1999. The correlation between climatic parameters and the retreat and advance of Franz Josef Glacier, New Zealand. Global Planet. Change, 22(1-4), 39-48.

Houghton, J.T. and 7 others. 2001. Climate change 2001: the scientific basis. Contribution of Working Group I to the Third Assessment Report of the Intergovernmental Panel on Climate Change. Cambridge, etc., Cambridge University Press.

Jacobs, J.D., É.L. Simms and A. Simms. 1997. Recession of the southern part of Barnes Ice Cap, Baffin Island, Canada, between 1961 and 1993, determined from digital mapping of Landsat TM. J. Glaciol., 43(143), 98-102.

Jin, R., L. Xin, T. Che, L. Wu and P. Mool. 2005. Glacier area changes in the Pumqu river basin, Tibetan Plateau between the 1970s and 2001. J. Glaciol., 51(175), 607-610.

Justice, C.O., S.W. Wharton and B.N. Holben. 1981. Application of digital terrain data to quantify and reduce the topographic effect on Landsat data. Int. J. Remote Sensing, 2(3), 213-230.

Kääb, A. 2002. Monitoring high-mountain terrain deformation from repeated air- and spaceborne optical data: examples using digital aerial imagery and ASTER data. ISPRS J. Photogramm. Rem. Sens, 57(1-2), 39-52.

Kääb, A. 2005. Combination of SRTM3 and repeat ASTER data for deriving alpine glacier flow velocities in the Bhutan Himalaya. Remote Sens. Environ., 94(4), 463-474.

Kerr, R.A. 2006. Yes, it's been getting warmer in here since the $\mathrm{CO}_{2}$ began to rise. Science, 312(5782), 1854.

Khalsa, S.J.S., M.B. Dyurgerov, T. Khromova, B.H. Raup and R. Barry. 2004. Space-based mapping of glacier changes using ASTER and GIS tools: learning from Earth's shapes and colors. IEEE Trans. Geosci. Remote Sens., 42(10), 2177-2183.

Khromova, T.E., G.B. Osipova, D.G. Tsvetkov, M.B. Dyurgerov and R.G. Barry. 2006. Changes in glacier extent in the eastern Pamir, Central Asia, determined from historical data and ASTER imagery. Remote Sens. Environ., 102(1-2), 24-32.

Kriegler, F.J., W.A. Malila, R.F. Nalepka and W. Richardson. 1969. Preprocessing transformations and their effects on multispectral recognition. In Proceedings of the 6th International Symposium on Remote Sensing of the Environment, Ann Arbor, Michigan, USA. Ann Arbor, MI, University of Michigan. Institute of Science and Technology, 97-109.

Larsen, N.K., J.A. Piotrowski, P. Christoffersen and J. Menzies. 2006. Formation and deformation of basal till during a glacier surge; Elisebreen, Svalbard. Geomorphology, 81(1-2), 217-234.

Liu, S., Y. Shen, W. Sun and G. Li. 2002. Glacier variation since the maximum of the Little Ice Age in the western Qilian Mountains, northwest China. J. Glaciol. Geocryol., 24(3), 227-233. [In Chinese with English abstract.]

Liu, X. and B. Chen. 2000. Climatic warming in the Tibetan Plateau during recent decades. Int. J. Climatol., 20(14), 1729-1742.

Lu, A., T. Yao, S. Liu, L. Ding and G. Li. 2002. Glacier change in the Geladandong area of the Tibetan Plateau monitored by remote sensing. J. Glaciol. Geocryol., 24(5), 559-562. [In Chinese with English abstract.]

Mayewski, P.A. and P.A. Jeschke. 1979. Himalayan and transHimalayan glacier fluctuations since AD 1812. Arct. Alp. Res. 11(3), 267-287.

Meier, M.F. 1973. Evaluation of ERTS imagery for mapping and detection of changes of snowcover on land and on glaciers. In Freden, S.C., E.P. Mercanti and D.E. Witten, eds. Symposium on Significant Results Obtained from Earth Resources Technical Satellite-1, (New Carrollton, Maryland). Washington, DC, National Aeronautics and Space Administration, 863-875.

Meier, M.F. 1984. Contribution of small glaciers to global sea level. Science, 226(4681), 1418-1421.

Miller, K.J., ed. 1984. The International Karakoram Project. Proceedings of the International Conference. Cambridge, Cambridge University Press.

Oerlemans, J. 1994. Quantifying global warming from the retreat of glaciers. Science, 264(5156), 243-245.

Oerlemans, J. 2005. Extracting a climate signal from 169 glacier records. Science, 308(5722), 675-677.

Paul, F. 2001. Evaluation of different methods for glacier mapping using Landsat TM. EARSeL eProc., 1, 239-245.

Paul, F., A. Kääb, M. Maisch, T. Kellenberger and W. Haeberli. 2002. The new remote-sensing-derived Swiss glacier inventory. I. Methods. Ann Glaciol., 34, 355-361.

Paul, F., C. Huggel and A. Kääb. 2004. Combining satellite multispectral image data and a digital elevation model for mapping debris-covered glaciers. Remote Sens. Environ., 89(4), 510-518.

Raup, B.H., H.H. Kieffer, T.M. Hare and J.S. Kargel. 2000. Generation of data acquisition requests for the ASTER satellite instrument for monitoring a globally distributed target. IEEE Trans. Geosci. Remote Sens., 38(2), 1105-1112.

Sakai, A., K. Fujita, K. Duan, J. Pu, M. Nakawo and T. Yao. 2006. Five decades of shrinkage of July 1 st glacier, Qilian Shan, China. J. Glaciol., 52(176), 11-16.

Shi, Y. and G. Cheng. 1991. Cryosphere and global climate change. Bull. Chinese Acad. Sci., 6(4), 287-291. 
Silverio, W. and J.M. Jaquet. 2005. Glacial cover mapping (19871996) of the Cordillera Blanca (Peru) using satellite imagery. Remote Sens. Environ., 95(3), 342-350.

Stevens, N., H. Garbeil and P.J. Mouginis-Mark. 2004. NASA EOS Terra ASTER: volcanic topographic mapping and capability. Remote Sens. Environ., 90(3), 405-414.

$\mathrm{Su}, \mathrm{Z}$. and Y. Shi. 2002. Response of monsoonal temperate glaciers to global warming since the Little Ice Age. Quat. Int., 97-98, 123-131.

Vincent, R.K. 1973. Spectral ratio imaging methods for geological remote sensing from aircraft and satellites. In Anson, A., ed. Proceedings of the American Society of Photogrammetry, Management and Utilization of Remote Sensing Data Conference, Sioux Falls, South Dakota. Falls Church, VA, American Society of Photogrammetry, 377-397.

Williams, R.S., Jr, D.K. Hall and J.Y.L. Chien. 1997. Comparison of satellite-derived with ground-based measurements of the fluctuations of the margins of Vatnajökull, Iceland, 1973-92. Ann. Glaciol., 24, 72-80.

Yang, J., Y. Ding, S. Liu, A. Lu and R. Chen. 2003. Glacier change and its effect on surface runoff in the source regions of the Yangtze and Yellow rivers. J. Natur. Res., 18(5), 595-602. [In Chinese with English abstract.]

Yao, T.D., Y.Q. Wang, S.Y. Liu, J.C. Pu, Y.P. Shen and A.X. Lu. 2004. Recent glacial retreat in High Asia in China and its impact on water resource in Northwest China. Sci. China D, 47(12), 1065-1075.

Ye, Q., T. Yao, S. Kang, F. Chen and J. Wang. 2006. Glacier variations in the Naimona'nyi region, western Himalaya, in the last three decades. Ann. Glaciol., 43, 385-389.

Zheng, D. and L. Zhu, eds. 2003. Formation, environment and development of the Tibetan Plateau. Shijiazhuang, Heibei Science and Technology Press.

MS received 10 November 2005 and accepted in revised form 1 October 2006 